\title{
Effectivity Analysis of the Decontamination Products for Radioactive Materials Used in Nuclear Medicine
}

\author{
Hayrettin EROĞLU' ${ }^{1}$ Oğuz AKSAKAL ${ }^{2}$
}

\begin{abstract}
In this study, several decontamination products were analysed in terms of their efficiency in decontaminating the radioactives ${ }^{99 \mathrm{~m}} \mathrm{Tc},{ }^{18} \mathrm{~F}-\mathrm{DG},{ }^{131} \mathrm{I}$ and ${ }^{201} \mathrm{Tl}$ from contaminated surfaces. Furthermore, the performance of existing commercial washers was examined and it was observed that it was far from the desired levels. Also, it was determined that the temperature and $\mathrm{pH}$ were the most important factors in the decontamination process of ${ }^{99 \mathrm{~m}} \mathrm{Tc}$ where as alcohol had no effect. Based on the performed analysis, it was concluded that the most effective decontamination product was DM-D (Decontamination Material-D) for ${ }^{99 \mathrm{~m}} \mathrm{Tc},{ }^{18} \mathrm{~F}-\mathrm{DG},{ }^{131} \mathrm{I}$ and ${ }^{201} \mathrm{Tl}$. Effectiveness analysis of DM-D for ${ }^{99} \mathrm{~m}$ Tc contamination on various surfaces showed that decontamination was quite fast on scrubsand formica and that DM-D was very effective on skin but not on plastic floor covering material. The effectiveness of various molecular groups in the decontaminant was also investigated. As a result, the acetate group was observed as the most effective component of the decontaminant.
\end{abstract}

Keywords: Contamination, radioactive, technetium, decontamination

\section{Nükleer Tıpta Kullanılan Radyoaktif Materyaller için Dekontaminasyon Ürünlerinin Etkinliğinin Analizi}

ÖZET: Bu çalışmada, radyoaktif Tc-99m, F-18-DG, I-131 ve Tl-201 ile kontamine olmuş yüzeylerin dekontaminasyonu için birçok dekontaminasyon malzemesinin etkinliği analiz edildi. Ayrıca mevcut ticari radyoaktivif temizleyicilerin performansları incelendi ve bunların beklenilen seviyelerden uzak olduğu gözlemlendi. Yine, yapılan çalışmalar sonucunda dekontaminasyon üzerine alkolün etkisinin olmadığı, sıcaklığın ve pH'ın ise Tc-99m'in dekontaminasyon sürecinde önemli faktörler olduğu belirlendi. Yapılan analizler 1şı̆̆ında, Tc-99m, F-18-DG, I-131 ve Tl-201 için en etkili dekontaminasyon ürününün DM-D (Dekontaminasyon materyal-D) olduğu sonucuna varıldı. Tc-99m ile kontamine olmuş çeşitli yüzeylerdeki DM-D’nin etkinlik analizi dekontaminasyonun formika ve giysiler üzerinde oldukça hızlı olduğunu ve DM-D’nin deri üzerinde çok etkili olduğunu ancak kaplama materyali plastik olan zemin üzerinde hiçbir etkisinin olmadığını gösterdi. Ayrıca, dekontaminasyondaki çeşitli moleküler grupların etkinliği incelendi. Sonuç olarak, asetat grubunun dekontaminasyonda en etkili komponent olduğu gözlemlendi.

Anahtar Kelimeler: Kontaminasyon, Radyoaktivite, Teknesyum, Dekontaminasyon

Atatürk Üniversitesi Mühendislik Fakültesi, Biyomedikal Mühendisliği Erzurum, Türkiye

Atatürk Üniversitesi Fen Bilimleri Enstitüsü, Nanobilim ve Nano Mühnedislik Anabilim Dalı, Erzurum, Türkiye

Sorumlu yazar/Corresponding Author: Hayrettin EROGLU, heroglu@atauni.edu.tr 


\section{INTRODUCTION}

Radiation poses great danger to human body and threatens both the environment and human life. Biological effects of radiation are very serious. Ionizing radiation causes variety of physical, chemical, and biological damages in living organisms at molecular and cellular levels (Görpe and Cantez, 1992). These damages can be temporary or persistent depending on the type, amount, and duration of the exposure to ionizing radiation. Ionizing radiations, such as $\mathrm{X}$ and gamma rays, alpha and beta particles, neutrons, and Auger electrons can cause changes at molecular level when they pass through the cells because they activate molecules and atoms inside the cell through ionization (Görpe and Cantez, 1992).

There is no cell that is completely resistant to radiation (Saha, 2010). Among the cell forming structures, the nucleus and in particular the chromosomes that are in the process of division are more susceptible to radiation than the cell cytoplasm. One of the most obvious effects of radiation at the cellular level is the suppression of the cell's growth. Especially during cell division (mitosis), the growth is interrupted in the cells exposed to radiation. In general, the cells with higher mitotic activity are considered to be even more susceptible to radiation. Radiation can lead to breaking, sticking together, adhering, and curling in chromosomes. Broken chromosomes can reorganize, remain the way it is, or combine with other chromosomes. All these changes can result in mutation or even go further and lead to the cell's death eventually. Apart from these, radiation can lead to the formation of giant cells. Cells exposed to radiation before the division takes place are no longer divisible, but may continue their metabolic activity for a period of time and continue to grow because they can't be divided anymore. They become giant cells and die in the end. Radiation may have devastating effects on the hematopoietic system, the lymphatic system, the reproductive system, the gastrointestinal system, skin, eyes, the central nervous system, and other organs (heart, kidneys, liver, pancreas, etc.) depending on the dose. These effects lead to changes over a period of time or may have a lasting impact (Görpe and Cantez, 1992; Eroglu et al., 2009).

Predominantly the employees working in places such as nuclear medicine centres where radiation is regularly used face these risks. The fact that employees are contaminated with radioactive material during patient injections as well as dose adjustment of radionuclide and its binding to pharmaceutical agents constitutes major risks. In addition to all these, particularly during patient injections performed under gamma cameras, the duration of contamination with the environment and the gamma camera affects the image. Hence, it is not possible to take any shots during this period, which consequently results in the loss of both time and labour.

There are three basic principles of radiation protection. These are comprised of implementing the rules for time, distance, and shielding. In order for these three principles to be implemented effectively, the contaminated part should be immediately cleaned and removed from the environment. Particularly, in the case where a body part of the employees gets contaminated, the contaminated area needs to be cleaned immediately in order to minimize the damage. Otherwise, the contamination keeps exposing the person to radiation until the radioactive material stabilizes. This, in turn, poses great risks to human life and labour productivity due to the abovementioned risks (Sampson, 1999; Kowalsky, 2011).

The aim of this study is to investigate the effectiveness of the materials used to clean the radioactive waste and to make recommendations for using the most effective materials. Existing decontamination materials were compared with newly developed materials and a benchmark of their efficiencies was obtained. For this purpose, most commonly used radionuclides in nuclear medicine such as ${ }^{131} \mathrm{I},{ }^{18} \mathrm{~F}-\mathrm{DG}$ (Fluorodeoxyglucose), ${ }^{201} \mathrm{Tl},{ }^{99 \mathrm{~m}} \mathrm{Tc}-$ Pertechnetate, ${ }^{99 \mathrm{~m} T c-D T P A,}{ }^{99 \mathrm{~m}} \mathrm{Tc}-\mathrm{DMSA},{ }^{99 \mathrm{~m}} \mathrm{Tc}-$ MDP, and ${ }^{99 \mathrm{~m}} \mathrm{Tc}-\mathrm{MIBI}$ were used as contaminants.

\section{MATERIALS AND METHODS}

One of the biggest problems for the employees working in nuclear medicine is the contamination that occurs during the operation. Not only the environment but also skins of the employees can get contaminated directly. For this reason, dead animal skins were used to create conditions similar to human skin in this study. Similarly, gloves, scrubs, plastic floor covering material, formica, and ceramic were chosen as the contaminated materials of a workspace.

Most commonly used materials in nuclear medicine,

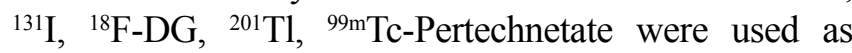
contaminants. The decaying scheme of radioactive materials is depicted in Table 1 (Alfassi et al., 2005; Saha, 2010). 
Table 1.The decaying scheme of radioactive materials

\begin{tabular}{|c|c|c|c|c|c|c|}
\hline \multirow{2}{*}{$\begin{array}{l}\text { Radioactive } \\
\text { Isotopes }\end{array}$} & \multirow[b]{2}{*}{ Half Life } & \multicolumn{2}{|c|}{ Gamma Rays } & \multicolumn{3}{|l|}{ X-Rays } \\
\hline & & $\begin{array}{l}\text { Energy } \\
(\mathrm{keV})\end{array}$ & $\begin{array}{l}\text { Emission } \\
\text { Probability (\%) }\end{array}$ & Energy $(\mathrm{keV})$ & $\begin{array}{l}\text { Emission } \\
\text { Probability (\%) }\end{array}$ & Assignment \\
\hline${ }^{18} \mathrm{~F}$ & $\begin{array}{l}109.77 \\
\text { Minutes }\end{array}$ & $511.00^{*}$ & 193.46 & & & \\
\hline \multirow{5}{*}{${ }^{131} \mathbf{I}$} & \multirow{5}{*}{ 8.02 Days } & 80.185 & 2.62 & \multirow{2}{*}{29.461} & \multirow{2}{*}{1.40} & \multirow{2}{*}{$\mathrm{Xe} \mathrm{K}_{\alpha 2}$} \\
\hline & & 284.305 & 6.14 & & & \\
\hline & & 364.489 & 81.70 & \multirow{3}{*}{29.782} & \multirow{3}{*}{2.59} & \multirow{3}{*}{ Xe $\mathrm{K}_{\alpha 1}$} \\
\hline & & 636.989 & 7.17 & & & \\
\hline & & 722.911 & 1.77 & & & \\
\hline \multirow{2}{*}{${ }^{99 \mathrm{~m}} \mathrm{Tc}$} & \multirow{2}{*}{6.01 Hours } & \multirow{2}{*}{140.511} & \multirow{2}{*}{89.00} & 18.251 & 2.15 & $\mathrm{Tc} \mathrm{K}_{\alpha 2}$ \\
\hline & & & & 18.367 & 4.10 & Tc $K_{\alpha 1}$ \\
\hline \multirow{11}{*}{${ }^{201} \mathrm{Tl}$} & \multirow{11}{*}{$\begin{array}{l}72.912 \\
\text { Hours }\end{array}$} & \multirow{5}{*}{135.340} & \multirow{5}{*}{2.56} & 9.899 & 1.90 & $\mathrm{Hg} \mathrm{L}_{\alpha 2}$ \\
\hline & & & & 9.989 & 16.90 & $\mathrm{Hg} \mathrm{L}_{\alpha 1}$ \\
\hline & & & & 11.824 & 10.10 & $\mathrm{Hg} \mathrm{L}_{\beta 1}$ \\
\hline & & & & 11.915 & 4.13 & $\mathrm{Hg} \mathrm{L}_{\beta 2}$ \\
\hline & & & & 11.992 & 1.80 & $\mathrm{Hg} \mathrm{L}_{\beta 3}$ \\
\hline & & \multirow{6}{*}{167.430} & \multirow{6}{*}{10.00} & 13.830 & 2.06 & $\mathrm{Hg} \mathrm{L}_{\mathrm{g} 1}$ \\
\hline & & & & 68.894 & 27.00 & $\mathrm{Hg} \mathrm{K}_{\alpha 2}$ \\
\hline & & & & 70.818 & 46.00 & $\mathrm{Hg} \mathrm{K}_{\alpha 1}$ \\
\hline & & & & 79.824 & 5.45 & $\mathrm{Hg} \mathrm{K}_{\beta 3}$ \\
\hline & & & & 80.255 & 10.50 & $\mathrm{Hg} \mathrm{K} \mathrm{K}_{\beta 1}$ \\
\hline & & & & 82.473 & 3.78 & $\mathrm{Hg} \mathrm{K}_{\beta 2}$ \\
\hline
\end{tabular}

* Subsequently emitted as annihilation radiation from $0.633 \mathrm{MeV}$ positron $\left(\beta^{+}\right)+$of $96 \%$ branching ratio

The radioactive material contaminated with approximately $1000 \mu \mathrm{Ci}$ was placed on the chosen surface and the contaminant was allowed to penetrate to the surface for one hour.

Six types of material shown in Table 2 were used as decontamination materials. $\mathrm{pH}$ values of the aqueous decontamination solutions of each substance were adjusted and tested. The contamination materials were cleaned with pure water and decontamination agents.

${ }^{99 \mathrm{~m}} \mathrm{Tc}$ was used in determining the effect of temperature, $\mathrm{pH}$, stirring speed, surface type, alcohol and the effective content of decontaminant material. The most effective decontaminant was also tested with other radioactive materials $\left({ }^{131} \mathrm{I},{ }^{18} \mathrm{~F}-\mathrm{DG},{ }^{201} \mathrm{Tl}\right)$ in order to see and compare the decontamination performance. 
Table 2. Decontamination materials and the active ingredients available in their contents

\begin{tabular}{lllll}
\hline $\begin{array}{l}\text { Decontamination Material } \\
\text { (DM) }\end{array}$ & pH & Alcohol & $\begin{array}{l}\text { Non-ionic surface } \\
\text { active agent }\end{array}$ & Other contents \\
\hline Water & 6 & - & - & - \\
$\begin{array}{l}\text { Commercial radioactive } \\
\text { decontaminant }\end{array}$ & 5 & Unknown & Unknown & Unknown \\
$\begin{array}{l}\text { A (Liquid Soap) } \\
\text { B (Surface Cleaner) }\end{array}$ & 6.5 & - & - & - \\
& 3 & - & present & Organic and inorganic \\
C (Surface Cleaner) & 7 & present & present & - \\
$\begin{array}{l}\text { D (Specially Developed Multi- } \\
\text { Purpose Cleaner) }\end{array}$ & 11 & - & & Acetate group, phosphate \\
\hline
\end{tabular}

CAPINTEC Radioisotope Calibrator was used to measure the amount of the contamination. The material contaminated with radioactive isotopes was placed in a beaker and decontamination was performed under pre-determined conditions such as fixed temperature, the weight of cleaning agent, and the stirring speed. The same conditions were created for each cleaning agent to make sure that the differences between them are clearly visible. The amount of radioactivity was measured on the material to be decontaminated before and after decontamination, and the effectiveness of the decontamination agents was measured.

\section{RESULTS AND DISCUSSION}

Following the surface contamination, radioactive materials were decontaminated under the initial conditions of $20{ }^{\circ} \mathrm{C}$ ambient temperature, $1 \mathrm{~L}$ liquid volume, $600 \mathrm{rpm}$ stirring speed, $1 \mathrm{gL}^{-1}$ cleaning agent weight.
Initially, in orderto determine which decontaminating agent was more effective, six different decontamination activities were performed and the results were compared. First, the decontamination results obtained with plain water was determined as a comparison parameter for other decontaminating products. As can be seen in Figure 1, DM-D was the most effective decontamination material among the other five cleaning products. As depicted in this figure, within the first 30 minutes, the decontaminating agents were able to decontaminate the material by $76.3 \%$ in the case of water; $80.2 \%$ in the case of radioactive decontaminant; $77.8 \%$ in the case of DM-A, $69.5 \%$ in the case of DM-B; and $43 \%$ in the case of DM-C, whereas the performance of DM-D was $85.7 \%$. 


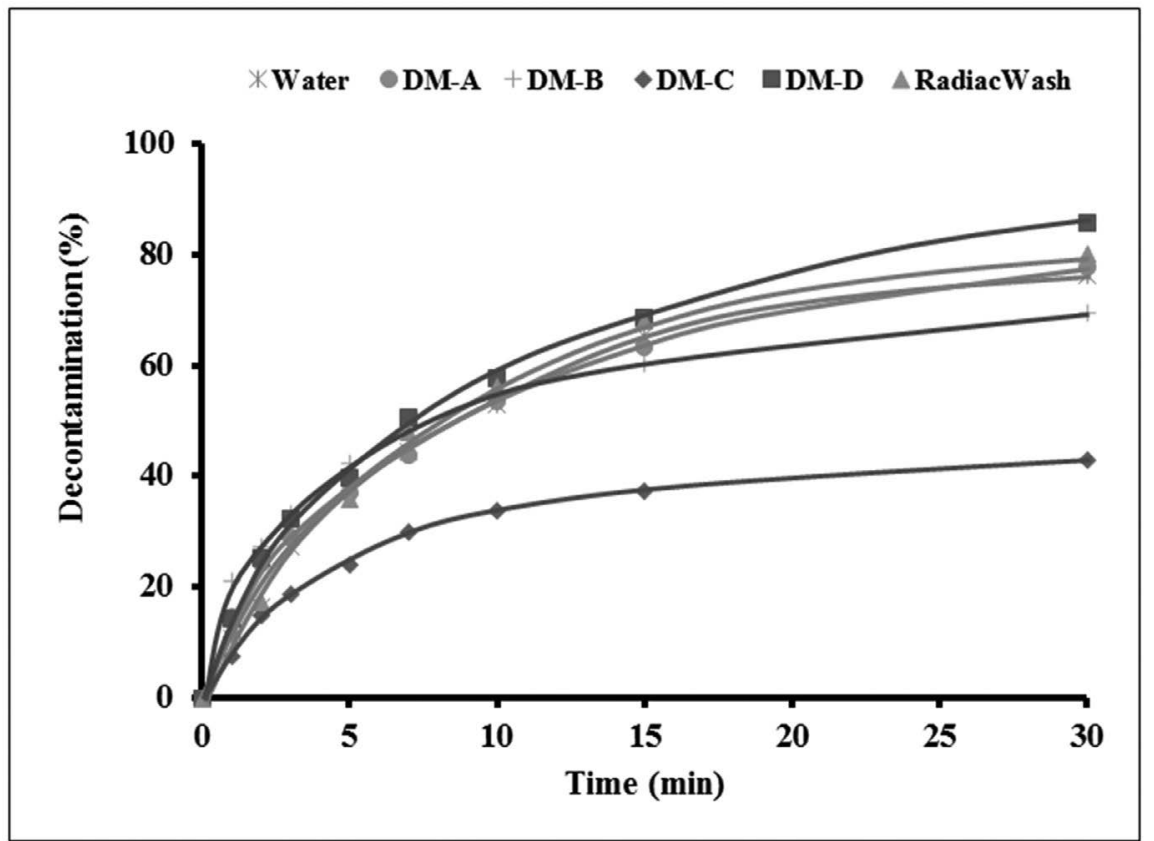

Figure 1. Decontamination effect of the decontamination materials on the contaminated skin

The effectiveness of the commercial radioactive decontaminant was observed to be more than the water, DM-A, DM-B and DM-C; however, not as much as DM-D.

In order to analyse the effect of $\mathrm{pH}$ on decontamination, the solutions were prepared by adding $1 \mathrm{~g}$ DM-D to $1 \mathrm{~L}$ water.The $\mathrm{pH}$ of these solutions was adjusted as 2.5, 4.0, 6.0,10.0 and 11.0. The $\mathrm{pH}$ of $1 \mathrm{gL}^{-1}$ DM-D aqueous solution used in measurements was measured as 8.9. The results are given in Figure 2. According to these results, it is observed that an increase in the $\mathrm{pH}$ causes an increase in the decontamination rate. The decontamination rates of the solutions with $\mathrm{pH}$ of 10.0 and 11.0 are quite close to each other.

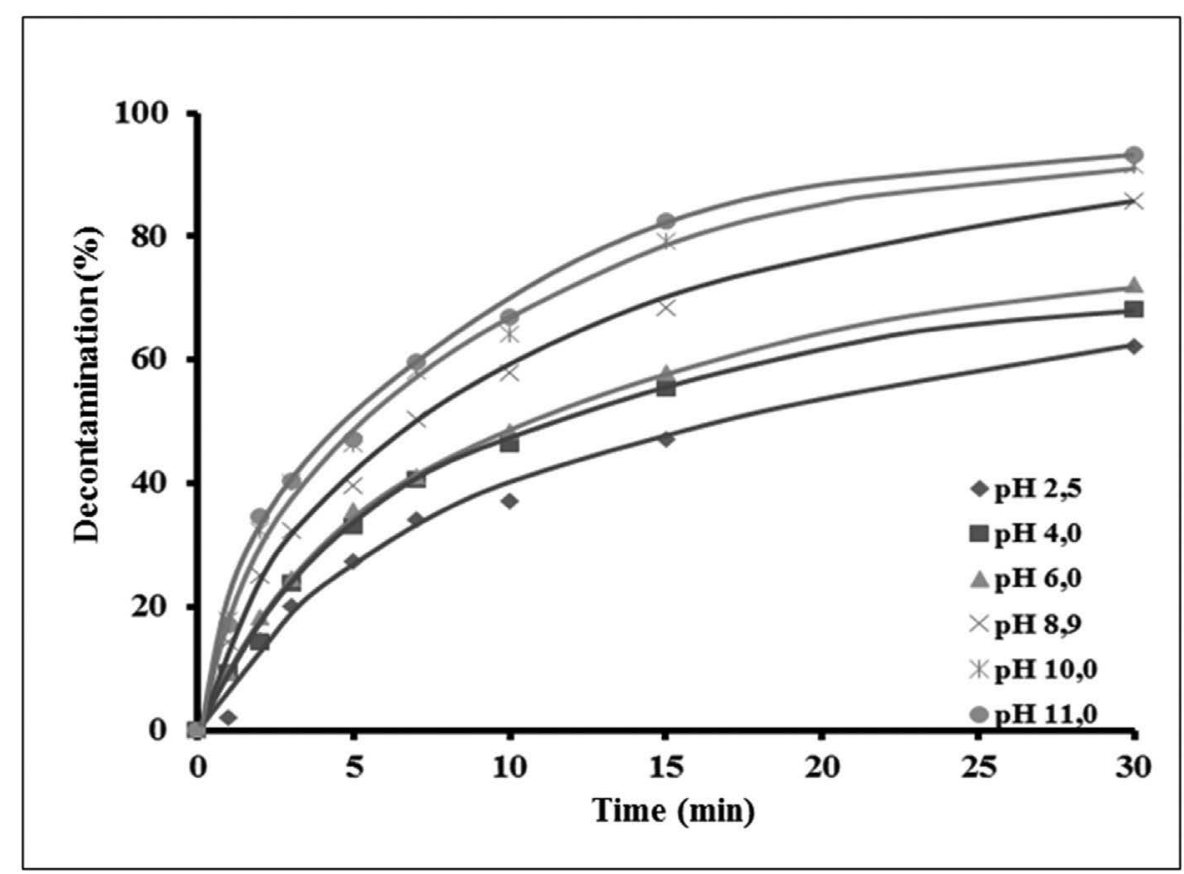

Figure 2. The effect of $\mathrm{pH}$ on decontamination 
It was observed that the effectiveness was decreased when alcohol (Isopropyl) was added to the decontamination material. As seen in Figure 3, the resulting values dropped to $84.11 \%, 80.44 \%, 74.86 \%$,
$71.58 \%$ with the addition of alcohol of $1 \%, 2 \%, 3 \%$, $5 \%$, respectively. These results showed that the addition of alcohol to the decontaminant material had a negative effect on the decontamination of ${ }^{99 \mathrm{~m}} \mathrm{Tc}$.

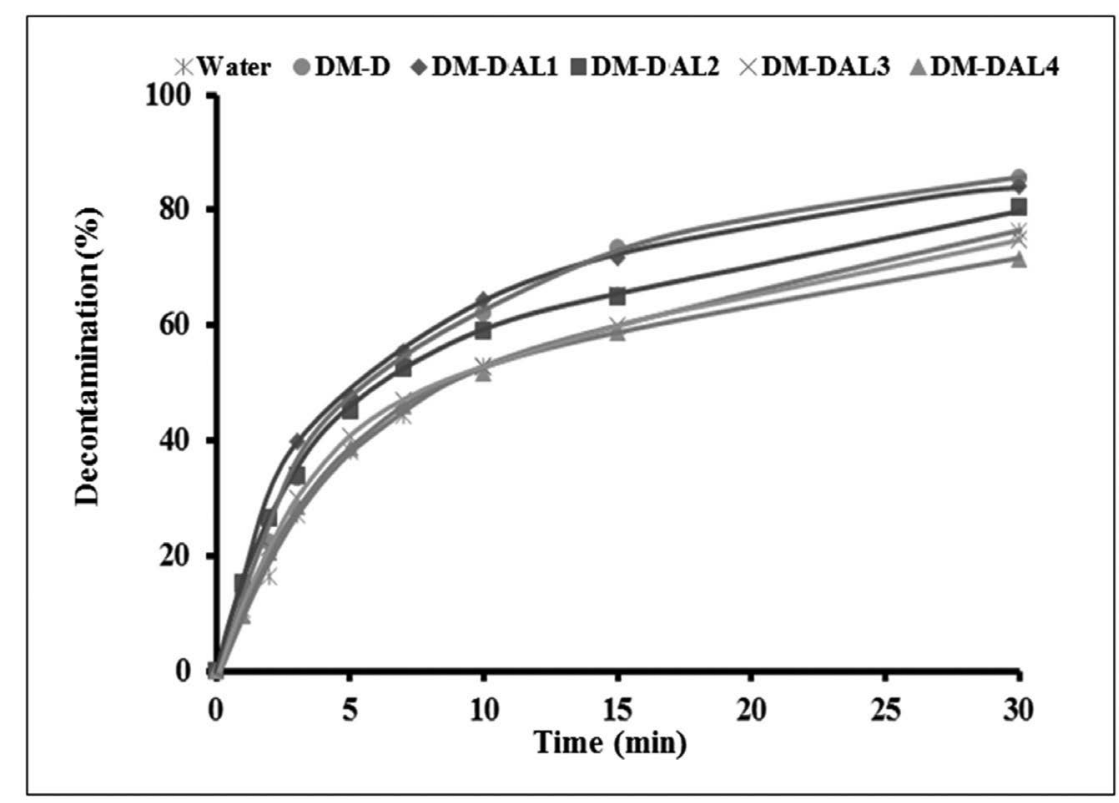

Figure 3. Decontamination effect of alcohol on the contaminated skin

It can also be seen in Figure 4 that the decontamination reaches $100 \%$ when the amount of DM-D is increased. Since there was little difference in terms of decontamination between 2,3 and $5 \mathrm{gL}^{-1}$ of DM-D and the decontamination reached its maximum level, it seemed unnecessary to work with higher amounts of DM-D. As a result, even small amounts of DM-D can be suggested as a quite effective agent in decontamination.

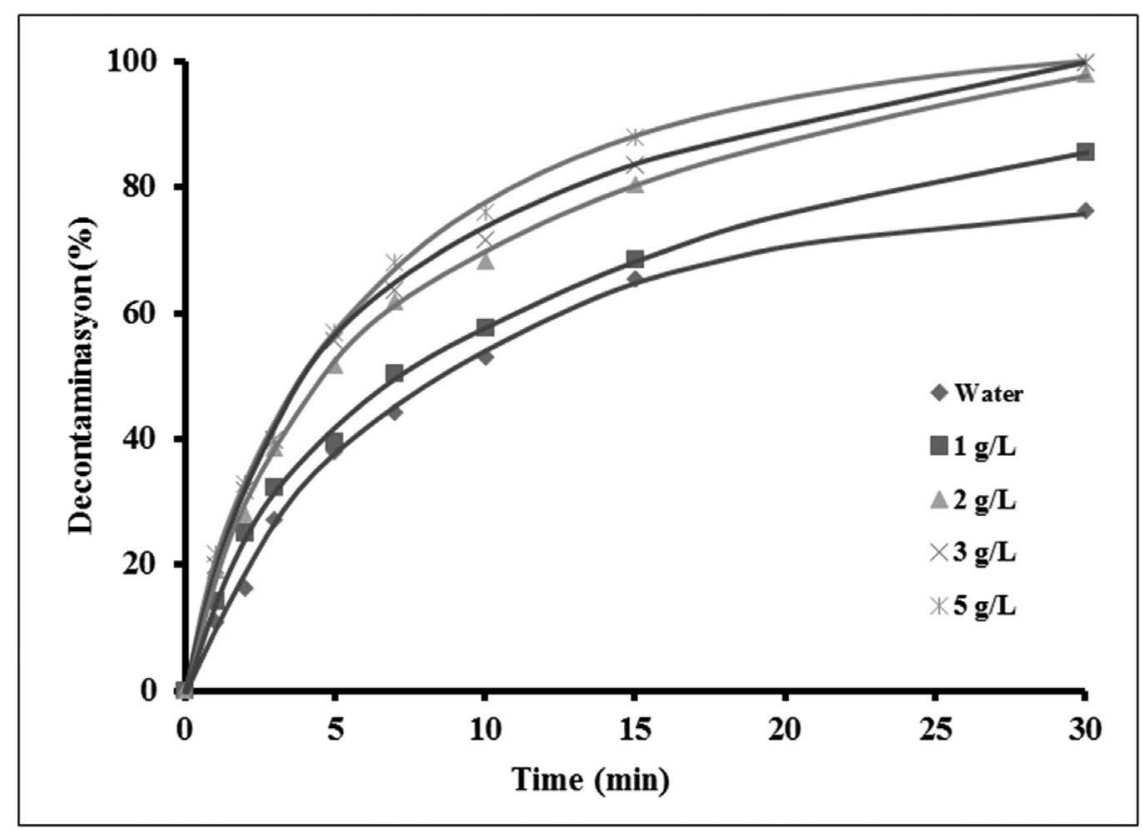

Figure 4. The effect of DM-D's amount on decontamination 
Among the parameters given in Figure 5, temperature was observed to be the most effective one. The temperature was varied between $10-40{ }^{\circ} \mathrm{C}$ and the data was examined. At the end of the $30^{\text {th }}$ minute, decontamination was at $47 \%$ at $10{ }^{\circ} \mathrm{C}$, whereas the most effective temperature was determined as $40{ }^{\circ} \mathrm{C}$ where the decontamination ratio reached $100 \%$. The fact that decontamination occurs at $40{ }^{\circ} \mathrm{C}$ suggests that ${ }^{99 \mathrm{~m}} \mathrm{Tc}$ attaches to the skin with a physical adsorption process. Since the pores in the skin hold ${ }^{99 m} \mathrm{Tc}$ physically, desorption takes place at a faster pace with increasing temperature (Smith, 1981; Beyhan, 2003;Aktins, 2010).

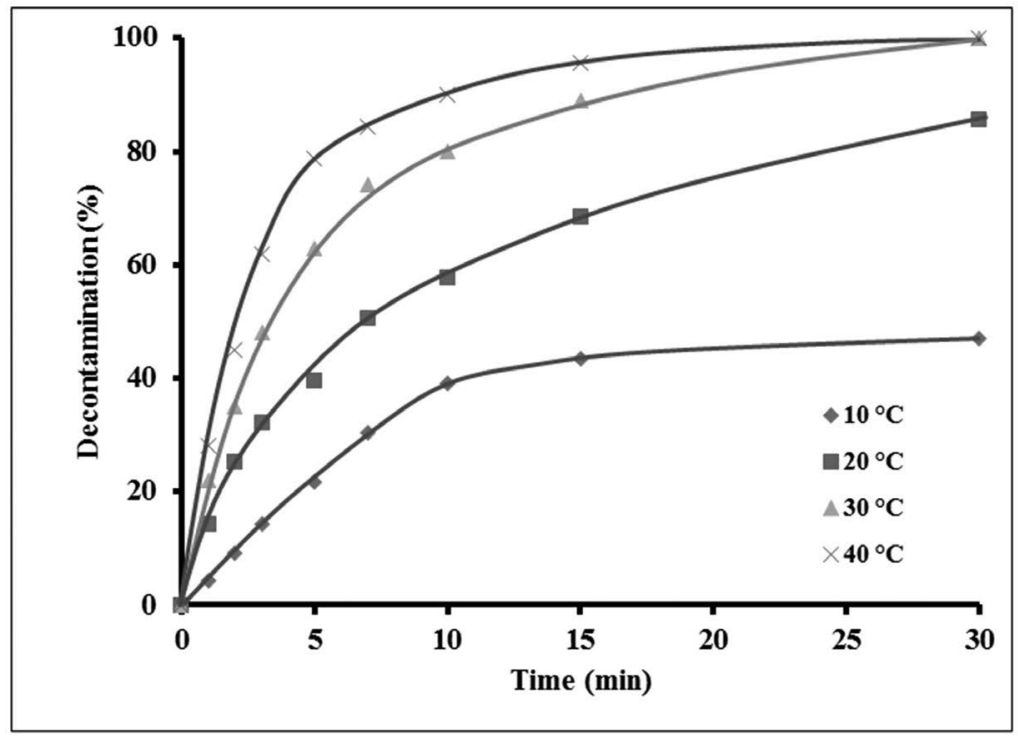

Figure 5. The effect of temperature on decontamination

The results were analysed for 5 different stirring speeds, determined as another parameter, and it is shown in Figure 6 that increasing the speed increases the decontamination ratio. When this graph is analysed, it is seen that at the end of the $30^{\text {th }}$ minute, $65,3 \%, 85,7 \%$ $88,3 \%$ and $88,9 \%$ decontamination rates are obtained at the stirring speed of $360 \mathrm{rpm}, 600 \mathrm{rpm}, 720 \mathrm{rpm}$ and $840 \mathrm{rpm}$, respectively. Since the decontamination rates for the speeds above $600 \mathrm{rpm}$ are quite close, the stirring speed is chosen as $600 \mathrm{rpm}$.

This result suggests that the film layer formed on the surface gets thinner with the increasing speed. It is a fact that as the film layer gets thinner; the resistance to desorption gets lower (Eroglu et al., 2009).

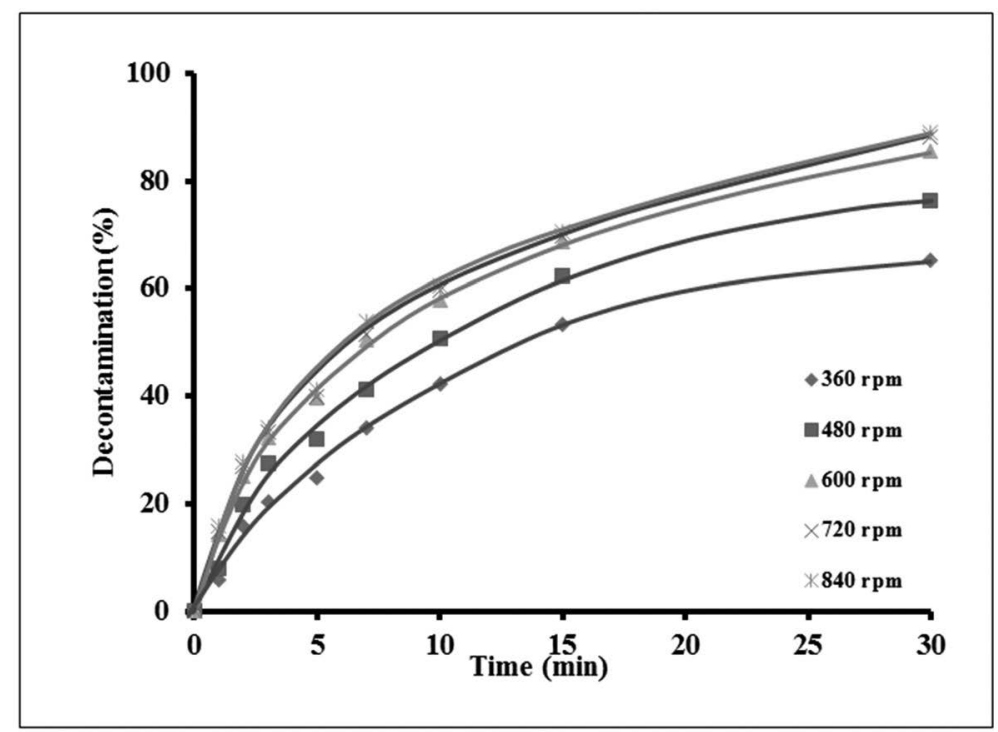

Figure 6. The effect of stirring speed on decontamination 
The decontamination effectiveness of DM-D was analysed by contaminating different materials with ${ }^{99} \mathrm{TcO}_{4},{ }^{99 \mathrm{~m}} \mathrm{Tc}-\mathrm{DTPA},{ }^{99 \mathrm{~m}} \mathrm{Tc}-\mathrm{DMSA},{ }^{99 \mathrm{~m}} \mathrm{Tc}-$ MDP and ${ }^{99 m}$ Tc-MIBI. The results between $5^{\text {th }}$ and $30^{\text {th }}$ min are given in Table 3 . As can be seen from the table, decontamination of ${ }^{99} \mathrm{TcO}_{4}$ reaches to high amounts in a very short duration for all surfaces. The decontamination effect of DM-D is very high for all surfaces except for ${ }^{99 \mathrm{~m}} \mathrm{Tc}$ DMSA contamination of skin and ceramic tiles. As the decontamination duration increases the effectiveness also increases. The most effective decontamination is realized with $100 \%$ in MIBIceramic decontamination.

Table 3. The effect of DM-D on different surfaces

\begin{tabular}{|c|c|c|c|c|c|c|}
\hline & \multicolumn{3}{|c|}{ Decontamination (\%) } & \multirow[b]{2}{*}{ DMSA } & \multirow[b]{2}{*}{ DTPA } & \multirow[b]{2}{*}{ MDP } \\
\hline & $\begin{array}{l}\text { Time } \\
\text { (min) }\end{array}$ & Pertechnetate & MIBI & & & \\
\hline \multirow{2}{*}{ Skin } & 5 th & 70.88 & 23.11 & 4.23 & 19.40 & 52.12 \\
\hline & 30 th & 96.60 & 34.67 & 21.17 & 51.74 & 74.54 \\
\hline \multirow{2}{*}{ Ceramic } & 5 th & 97.40 & 100.00 & 16.38 & 90.36 & 61.14 \\
\hline & 30 th & 97.59 & 100.00 & 21.83 & 90.36 & 68.86 \\
\hline \multirow{2}{*}{ Formica } & 5 th & 97.81 & 90.44 & 88.28 & 97.79 & 97.52 \\
\hline & 30 th & 98.76 & 90.44 & 96.31 & 98.68 & 99.04 \\
\hline \multirow{2}{*}{$\begin{array}{l}\text { Plastic Floor } \\
\text { Covering } \\
\text { Material }\end{array}$} & 5 th & 56.38 & 99.12 & 59.81 & 68.15 & 92.68 \\
\hline & 30 th & 62.31 & 99.12 & 71.77 & 68.15 & 94.19 \\
\hline \multirow{2}{*}{ Plastic Gloves } & 5 th & 96.83 & 35.97 & 57.88 & 62.81 & 91.45 \\
\hline & 30 th & 98.10 & 71.94 & 74.51 & 62.81 & 94.08 \\
\hline \multirow{2}{*}{ Scrubs } & $5 t h$ & 99.76 & 52.33 & 86.64 & 99.65 & 69.94 \\
\hline & $30 t h$ & 99.76 & 93.76 & 90.32 & 99.88 & 93.92 \\
\hline
\end{tabular}

In the light of these results, it is concluded that the decontamination of the surfaces is easier on formica and cottony surfaces than on composite materials such as skin, plastic, and ceramics. It is understood that the decontamination of adsorbed technetium from these types of materials is more difficult in comparison to less porous materials as a result of the experiment.

Decontamination of ${ }^{131} \mathrm{I},{ }^{18} \mathrm{~F}-\mathrm{DG}$ and ${ }^{201} \mathrm{Tl}$ 'in from skin by water, DM-D, and commercial radioactive decontamination material were analysed and the results were provided in Figure 7 . As can be seen from Figure $7 \mathrm{a}$ all three materials are very effective for the decontamination of ${ }^{131} \mathrm{I}$, and it is observed that there is no meaningful difference among them. Approximately $100 \%$ decontamination is achieved within the first five minutes for all three materials.
It is observed in Figure $7 \mathrm{~b}$ that DM-D is the most effective decontaminant for the decontamination of the FDG contamination on the skin. Even though the results get closer after 30 minutes, DM-D has higher decontamination rate for the first 10 minute results. Observed decontamination rates were $\% 86.1$ for water, $91.5 \%$ for commercial radioactive decontaminant, and 94.6\% for DM-D in the first 10 minutes.

When Figure $7 \mathrm{c}$ is analysed, the effectiveness of DM-D is clearly seen for the decontamination of ${ }^{201} \mathrm{Tl}$ on skin. The resulting decontamination rates for radioactive ${ }^{201} \mathrm{Tl}$ on skin at the end of $30^{\text {th }}$ minute are observed to be $\% 37.2$ for water, $\% 31.5$ for Radiawash and $66.1 \%$ for DM-D.

In the light of all these results, it can be concluded that DM-D is an effective decontaminant material not only for ${ }^{99 \mathrm{~m}} \mathrm{Tc}$ and its compounds but also for other radioactive materials. 


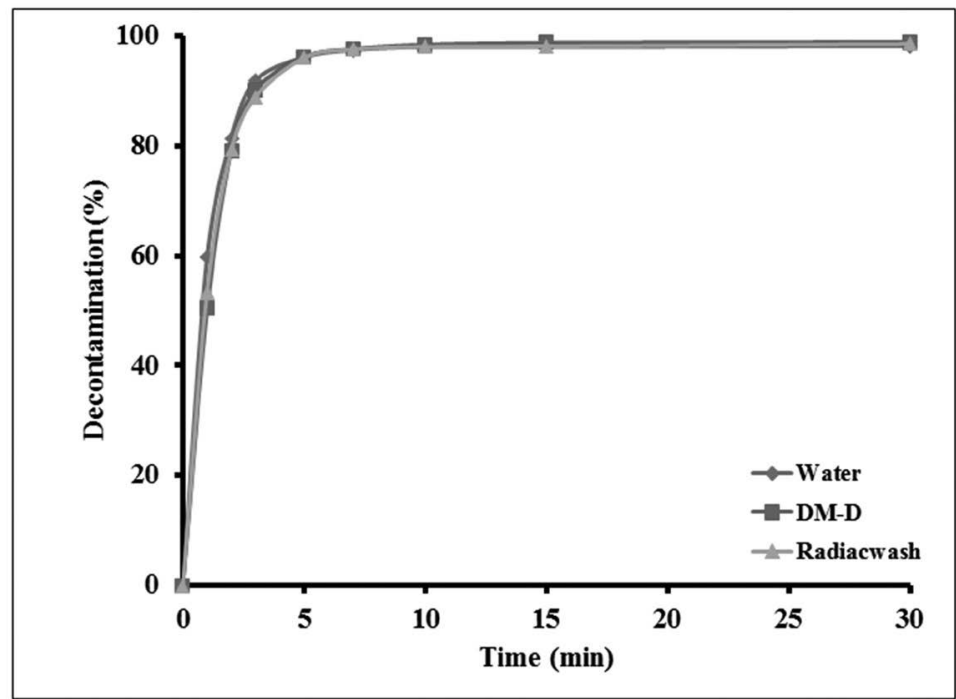

a- ${ }^{131} \mathrm{I}$

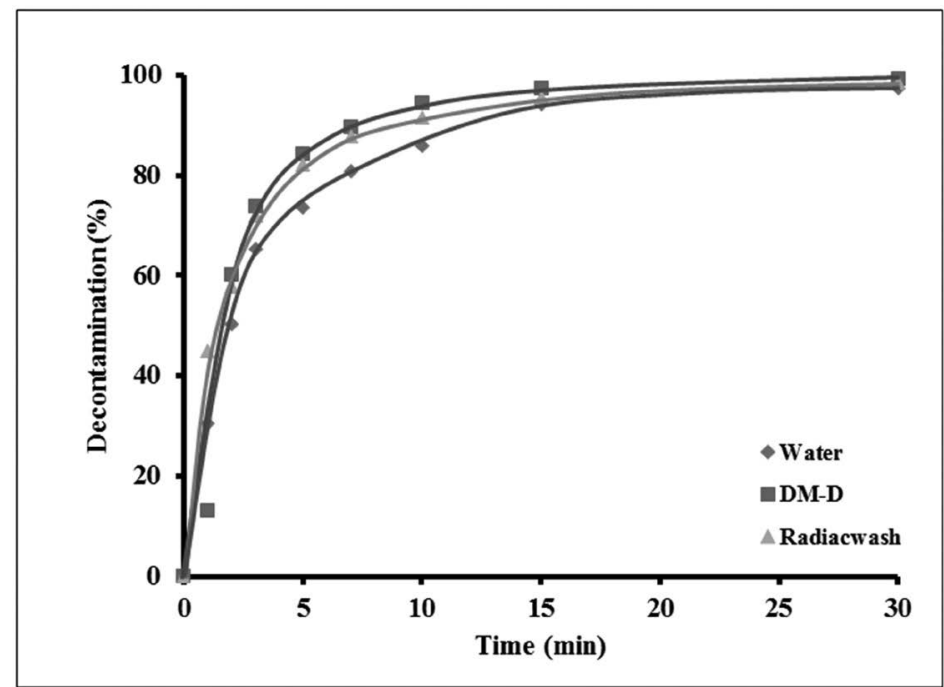

b- FDG

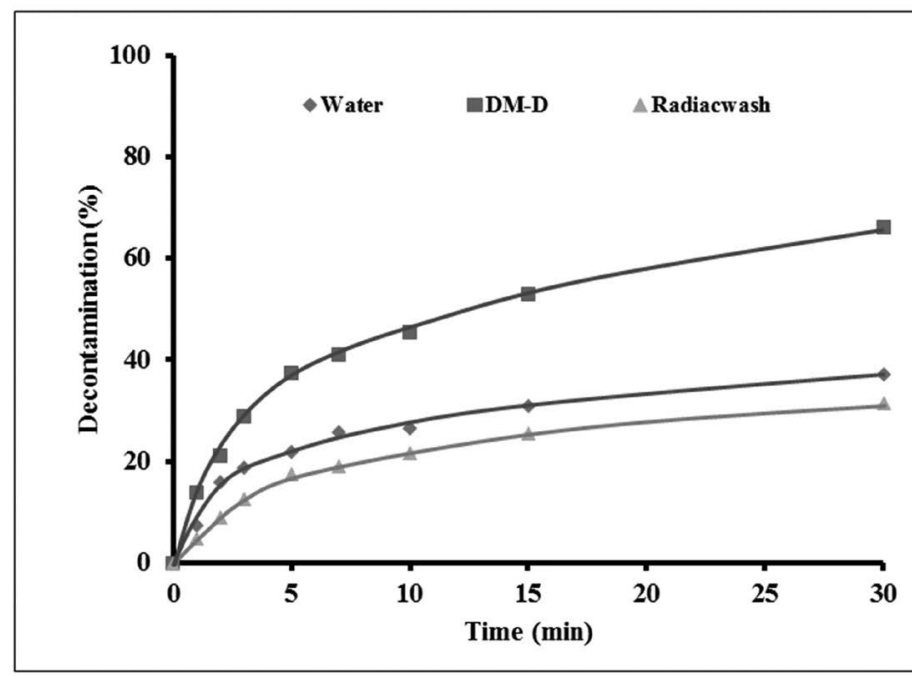

c- ${ }^{201} \mathrm{Tl}$

Figure 7. The decontamination effect of DM-D on ${ }^{18} \mathrm{~F}-\mathrm{DG},{ }^{131} \mathrm{I},{ }^{201} \mathrm{Tl}$ contamination 
${ }^{99 \mathrm{~m}}$ Tc-Pertechnetate is contaminated on skin in order to determine the material causing the increased decontamination effectiveness for DM-D. The effective groups in DMD, which are anionic and ionic group (DM-D1), phosphate group (DM-D2), acetate group (DM-D3) and combination of all (DM-D4) are increased about $1-2 \%$ and the results are shown in Figure 8 . Based on these results, while DM-D has $57.8 \%$ effectiveness, DM-D3 has reached to $71.6 \%$ effectiveness within the first 10 minutes. Similarly, at the end of $30^{\text {th }}$ minute, the decontamination effectiveness is observed to be $85.7 \%$ for DM-D and $88.5 \%$ for DM-D3. It is seen that DMD3 has faster decontamination rate than that of DM-D starting from the first minutes.

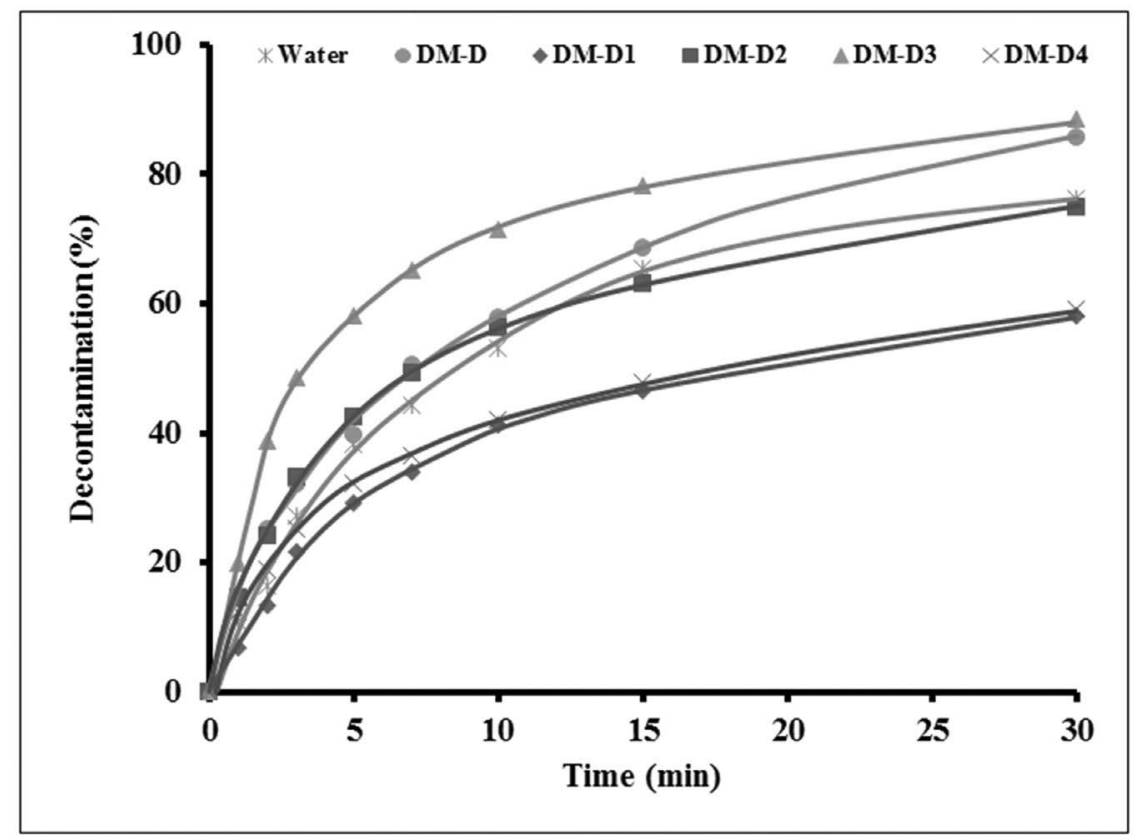

Figure 8. The effectiveness of different molecular groups in the decontaminant

When the results are analysed it can be suggested that, contrary to what is known, commercial radioactive decontaminants are not as much effective and the newly developed surface cleaners are more effective under the same conditions. When the results of the experiment are analysed, it is concluded that DM-D is observed to be the most effective decontaminant for all radioactive materials ${ }^{131} \mathrm{I},{ }^{18} \mathrm{~F}-\mathrm{DG}$ and $\left.{ }^{201} \mathrm{Tl}\right)$. As for ${ }^{99 \mathrm{~m}} \mathrm{Tc}$, the temperature is determined as the most effective parameter, and it is observed that desorption increases rapidly with the increasing temperature. In addition, while the results are positively affected by the increase in both the stirring speed and the amount of decontamination materials, alcohol (Isopropyl) has no effect. Also, increased alkalinity increases the efficiency of the decontamination. Maximum efficiency is obtained especially at $\mathrm{pH} 11$. Most importantly, acetate groups are determined to be the most effective active substance for decontamination

Due to the fact that cleaning conditions of washing machines are very close to the experimental conditions, long term washing at high temperatures with plenty of decontamination material can be applied in order to achieve the most effective decontamination rate. In addition, the experiments conducted on the surfaces have shown that decontamination of formica is better than that of plastic and ceramic-like materials. The porous structure of the materials is an important parameter for decontamination. Hence, selecting formica as tiling material can be said to be of particular importance in terms of human health. The fact that cotton clothes like scrubs are affected very little by contamination and decontaminated quickly suggests that cotton materials will provide significant advantages for the decontamination of radiation in the case of radioactive accidents. 


\section{CONCLUSION}

In the light of the results obtained in this study, it is recommended that the decontaminant products with high-pH levels, which contain high level of acetate content for centres such as nuclear medicine in which radioactive materials used, can be used for efficient decontamination. It is also recommended to apply high temperature during decontamination process. Another important issue is that workers should use cotton scrubs or similar clothes due to the fact that these materials have high decontamination rates for all radioactive materials used in this study. Also, formica is determined as the most appropriate floor covering material in this study. Although commonly used latex gloves is necessary to help preventing any skin damage on workers, it is realized in this study that these gloves can't be decontaminated well and should be removed and discarded with the radioactive waste immediately after the required laboratory work.

Based on the overall results, DM-D can be suggested as the most effective decontamination material.

\section{ACKNOWLEDGEMENT}

We would like to thank Is1l Chemical for providing their products and developing a product with the requested features for our use in this study, and for the financial support of Ataturk University for the project BAP-2013/336.

\section{REFERENCES}

Alfassi ZB, Groppi F, Bonardi ML, Goeij JJM de, 2005. On the "artificial" nature of Tc and the "carrier-free" nature of $99 \mathrm{mTc}$ from $9 \mathrm{Mo} / 99 \mathrm{mTc}$ generators. Appl. Radiat. Isotopes. $63,37-40$

Atkins PW, 2010. Physical Chemistry, Oxford Universty Pres, 9 Edition.

Beyhan M, 2003. Atık çamurlar v edoğal malzemeler ile sulardan florüriyonu gideriminin araştırılması, Doktora, YTÜ, Fen BilimleriEnstitüsü, İstanbul

Görpe A., Cantez S, 1992. Pratik Nükleer Tip, İstanbul Tip FakültesiVakfi, İstanbul, pp.1-42.

Eroglu H, Yapıcı S, Nuhoglu C, Varoglu E, 2009. An environmentally friendly process; adsorption of radionuclide Tl-201 on fibrous waste tea, J. Hazard.Mater 163, 607-617.

Kocher DC, 1981. Radioactive Decay Tablets, Technical Information Center, U.S. Department of Energy, DOE/TIC 11026, Washington, DC.
Kowalsky RJ, Falen SW, 2011. Radiopharmaceuticals in Nuclear Medicine Practice, American Pharmacists Association, 109127.

Saha GB, 2010. Fundamentals of Nuclear Pharmacy. Springer- Verlag, New York, Sixth Edution.

Sampson CB, 1999. Textbook of Radiopharmacy Theory and Practice, Gordon and Breach Science Publishers, pp. 125-244.

Smith JM, 1981. Chemical Engineering Kinetics, Mc- Graw- Hill İnternational Book London. 
